\title{
PROPOSAL OF THE SOUND INSULATING MEASURES FOR A VIBRATIONAL SORTER AND VERIFICATION OF THE MEASURED EFFECTIVENESS
}

\author{
Pavol Liptai' ${ }^{1}$ Marek Moravec ${ }^{1}$, Ervin Lumnitzer'1, Marcela Gergel'ová2 \\ 1 Technical University of Košice, Faculty of Mechanical Engineering, Letná 9, Košice, Slovakia, e-mail: pavol. \\ liptai@tuke.sk, marek.moravec@tuke.sk, ervin.lumnitzer@tuke.sk \\ 2 Technical University of Košice, Faculty of Mining, Ecology, Process Control and Geotechnologies, Letná 9, \\ Košice, Slovakia, e-mail: marcela.gergelova@tuke.sk
}

Received: 2017.05.15

Accepted: 2017.08.01

Published: 2017.09.03

\begin{abstract}
The paper describes a specific design of the sound insulating enclosure of a vibrating sorter. Recycling aspects have been taken into account when designing the enclosure, because recycled foam has been applied as a sound-absorbing material. An acoustic camera was used to measure, analyze, evaluate and to localise and identify sound sources. The visualization method was used to locate the critical locations of the device and then quantify them. To evaluate the effectiveness of the proposed enclosure, the measurements of the sound parameters were performed before and after the realization soundproofing measure. The measured results show the requested efficiency of the sound insulating enclosure in terms of noise reduction as well as dust near the sorter.
\end{abstract}

Keywords: sound insulating measures, vibrational sorter, noise visualization, analysis and measurement.

\section{INTRODUCTION}

The possible effects of the formation of undesirable conditions that may cause increased vibration of devices used predominantly in stone quarries are described more specifically in the publications $[1 \div 5]$.

When designing a noisy machine enclosure, we use structural elements to interrupt the propagation paths by the applications of sound absorbing materials and vibro-elastic material and elements. The enclosure must be designed with regard to the machine running checks, its repairs, disassembly and proper cooling during operation [6]. The design and calculation of acoustic enclosures, cabins and wrappings is given a great deal of attention in the book by Ver and Beranek in Chapter 12 [7].

Before designing the soundproofing measures of the technological devices, it is necessary to know the frequency of the sound that is calculated from the time recording of the sound. Such outputs can be obtained by conventional sound measurement techniques as well as modern technologies for measuring and visualizing sound [ $8 \div 11]$. Correct vibro-acoustic analysis of individual components of mechanical and electrical equipment is essential based on theoretical and practical knowledge published in books and publications as $[12 \div 20]$.

The sound insulation materials used for the application of the enclosures in heavy industrial installations are subject to high demands, particularly in terms of high sound insulation, dimensional stability, ease of handling and ability to withstand temperature changes and changes in air humidity. Requirements and recommended procedures for designing workstations and noise measures for workplaces with mechanical devices are given in STN EN ISO 11690-2: 1999 [27] as well as in works by Liptai. R.G. and Zajac $[21 \div 23]$. 


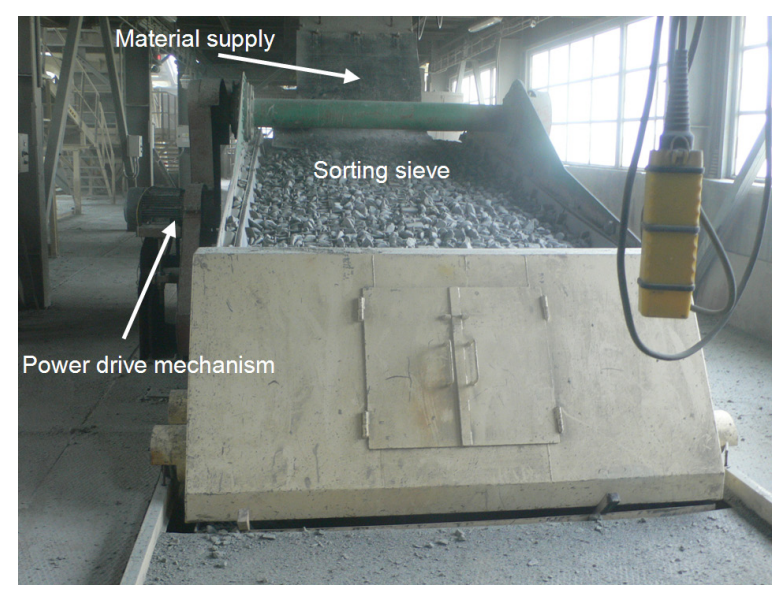

Fig. 1. Vibrational sorter

\section{EXPERIMENTAL PART}

Vibrational sorter (Fig. 1) is a device that serves to separate stone fractions of different sizes depending on the vibrating sieve used. The drive is provided by an electric motor, which is the driving element of the pulley and belt transmissions. The sieve gradient and the oscillation of the entire device cause the fraction to shift over the vibration sieve. The larger fraction is moved to the end into the buffer and the smaller fraction falls through the mesh sieve into the container and the next conveyor belt. The vibrating sorter is attached to the metal floor structure, which transmits oscillation from the floor to the surrounding structures.

\section{MATERIALS AND METHODS}

For the sound analysis of the device, we chose a method of measuring A - weighted equivalent sound pressure level and a method of

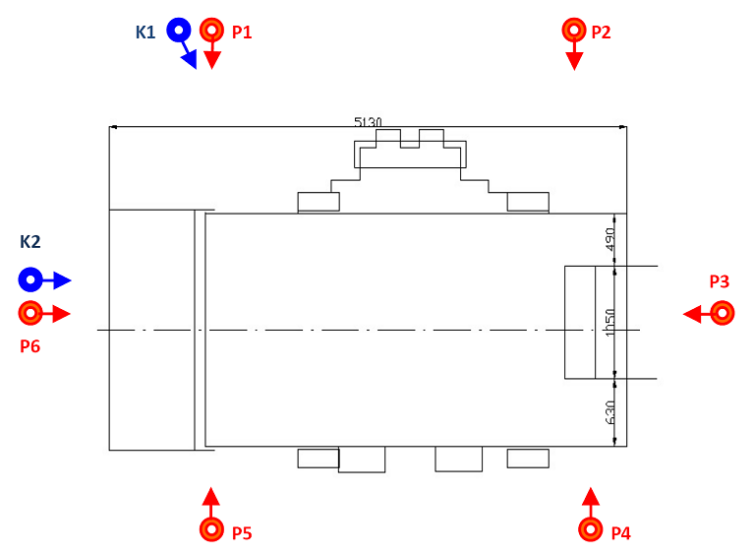

Fig. 2. Measurement points

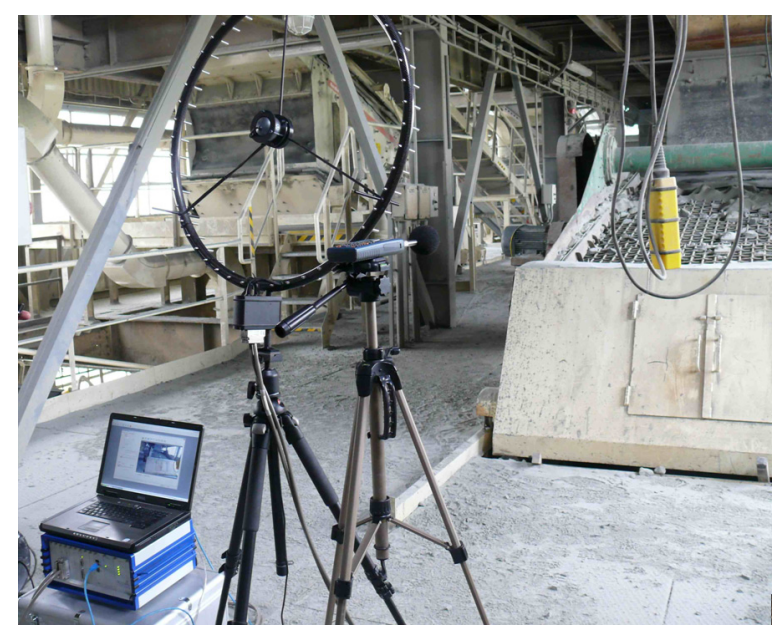

Fig. 3. The location of the acoustic camera and the sound analyzer at the measurement point P6 and K2

dynamic visualization of sound, which is very advantageous in terms of sound source localization. For measurement we used the Class 1 sound analyzer, Norsonic 140, and a circular microphone acoustic camera were used. This microphone array is designed primarily to identify sound sources of machines and equipment inside industrial plants and buildings.

At the measurement points indicated in Fig. 2 as P1-P6. 1-minute measurements were realized by the sound analyzer at a distance of 1.5 $\mathrm{m}$ from the structure of the sorter along its circumference. At the measuring points indicated in Fig. 2 as K1 and K2. 8-second acoustic camera measurements were taken during which all sources of sound that occurred throughout the measuring period were captured. The location of the acoustic camera and the sound analyzer at the measurement point P6 and K2 is shown in Fig. 3. The measurements were performed in two operating modes and in the case of the vibration sorter being on with sorting of stone fraction and without the sorting (no load of stone fraction). The stone fraction was up to $32 \mathrm{~mm}$. These same measurements were made even after the sound insulating enclosure was realized.

\section{ANALYSIS AND SOUND SOURCES LOCALIZATION}

Acoustic camera measurements help us better locate the devices noise sources. Acoustic images of quantitatively significant sources of noise are shown in Fig. 4 to Fig. 6 during the sorting of stone fraction. 


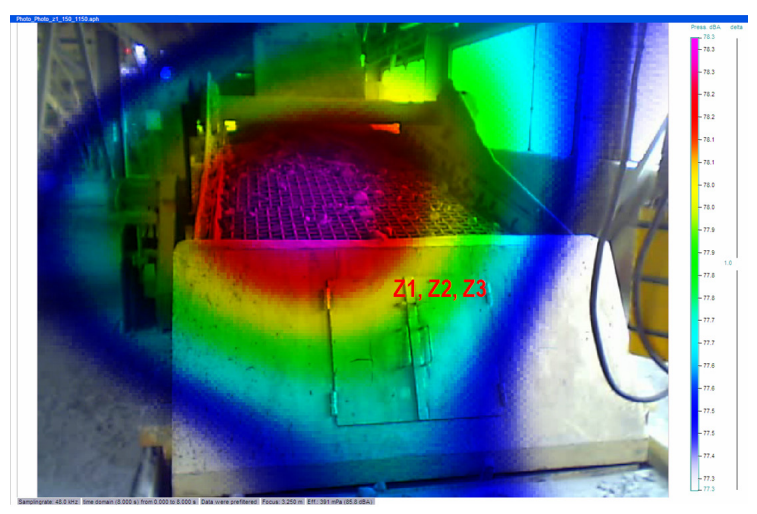

Fig. 4. Acoustic image for the frequency range from $150 \mathrm{~Hz}$ to $1150 \mathrm{~Hz}$

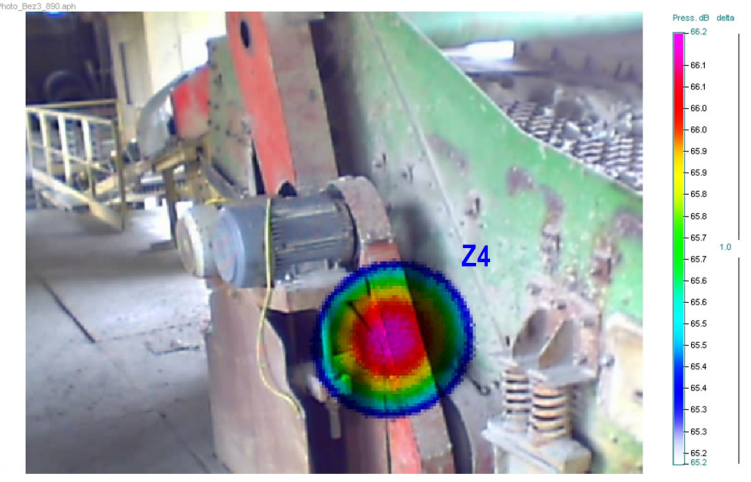

Fig. 5. Acoustic image for the frequency $890 \mathrm{~Hz}$

Classification of partial noise sources from the loudest to the least noisy is of great importance for the selection of noise measures. Based on the analysis carried out, the noise sources were classified according to significance in descending order:

- Z1 - Noise caused by the supply of material and the fall of the stone fraction on the metal parts and the vibrating screens;

- Z2 - Noise caused by moving the stone fraction to the sorter site;

- Z3 - Noise caused by the oscillation of the whole sorter;

- Z4 - Belt gear elements noise;

- Z5 - Electric motor noise.

The analysis of noise sources shows that the dominant source of noise is the fall of the stone fraction on the sorter construction and the shifting of the material along the site of the sorter. The realization of structural changes for noise reduction is very difficult and inefficient for this kind of noise sources. In addition, there could be an unwanted impact on the operating parameters, functionality and efficiency of the device. For these

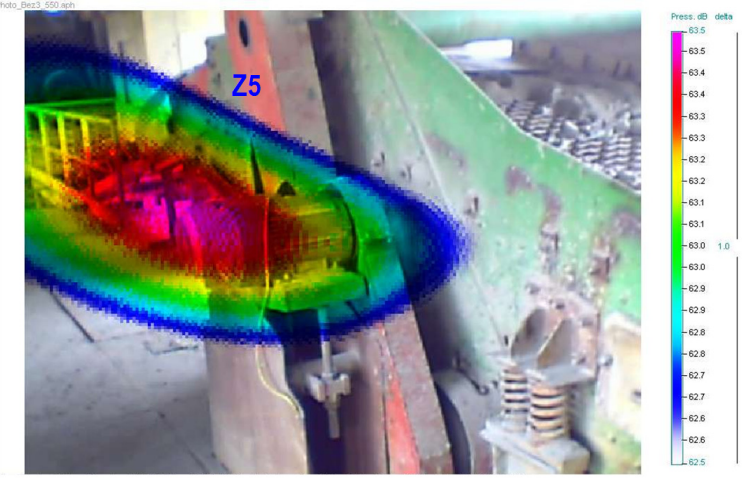

Fig. 6. Acoustic image for the frequency $690 \mathrm{~Hz}$

reasons, the most effective solution is to cover the entire vibrational sorter.

\section{DESIGN OF SOUND INSULATING ENCLOSURE}

From the point of view of the function and parameters of the device, we designed a sound insulating enclosure with access to maintenance of the sorting device, see Fig. 7. The design was realized with a flexible housing of wheels that allows movement of the enclosure. The avoidance of undesirable conditions was taken into account, (overheating, resonance, etc.). For realization are used oriented strand boards along the load-bear-
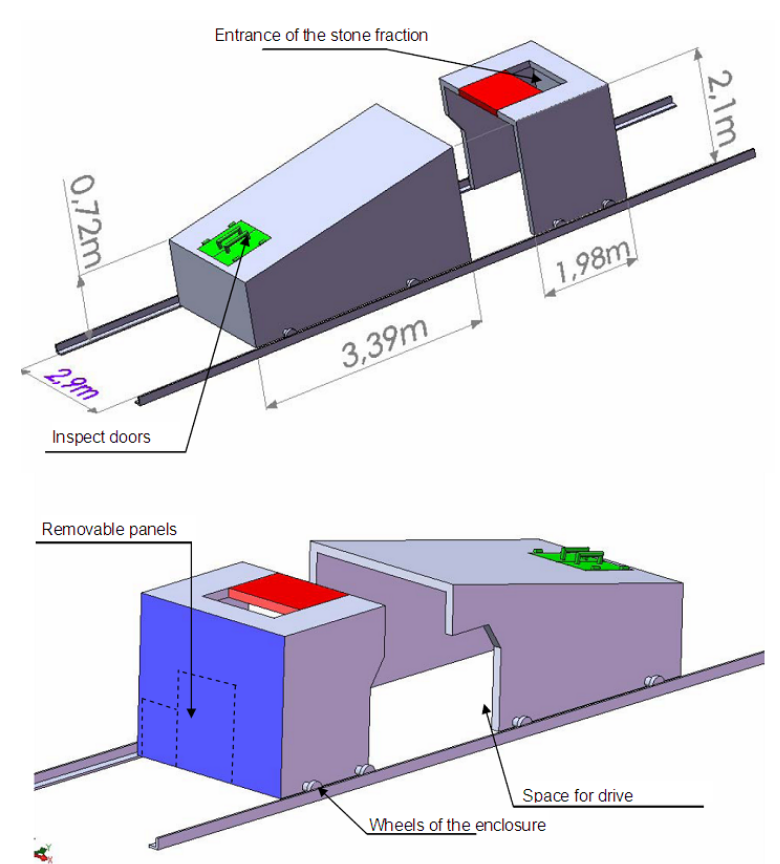

Fig. 7. 3D view of the enclosure design for vibrational sorter 


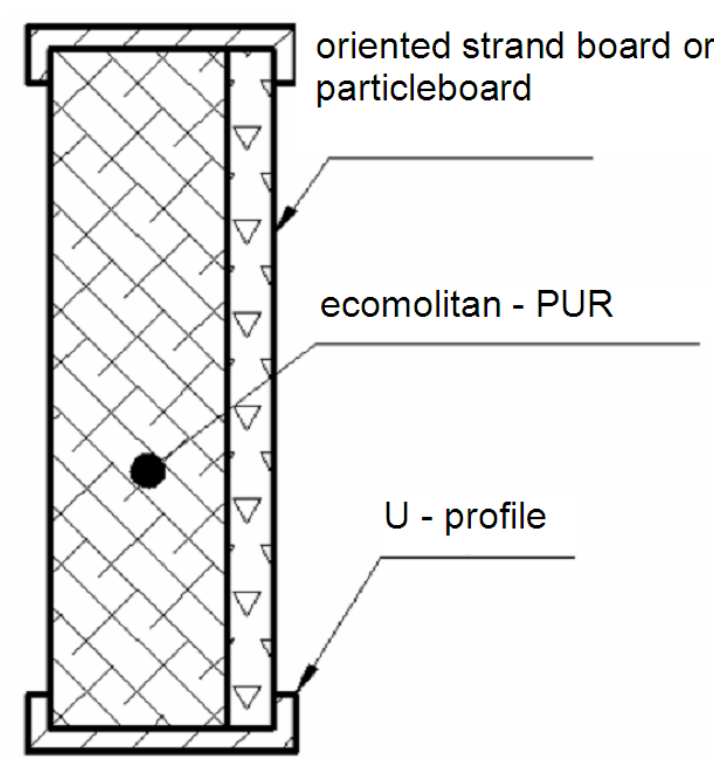

Fig. 8. Cross-section of the sandwich arrangement

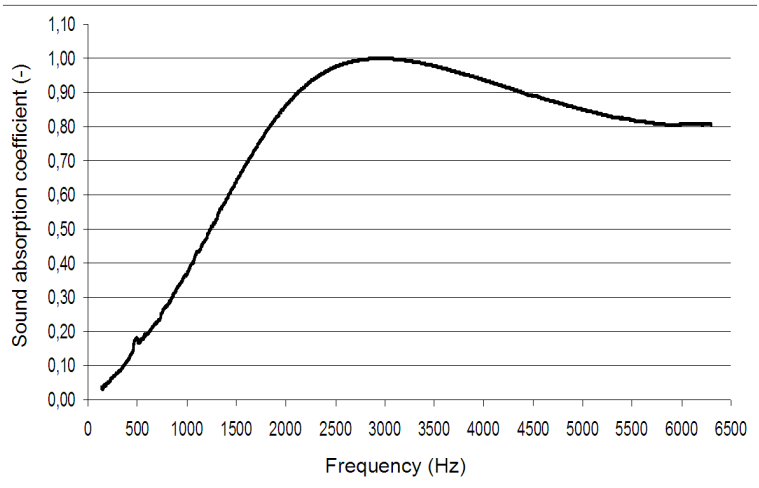

Fig. 9. Sound absorption coefficient of recycled polyurethane foam with recycled car seat cover thickness of $50 \mathrm{~mm}$

ing structure of the walls and the ceiling cover. The thickness of the inner filler of the sound insulating material for this cover design is min. 50 $\mathrm{mm}$. The cross-section of the sandwich arrangement of the sound insulating cover materials is shown in Fig. 8.

When designing an acoustically suitable material inside the sound insulating enclosure, we also took into account the recycling aspect. In terms of physical parameters, handling and efficiency, we have designed recycled polyurethane foam and recycled car seat covers for this application. The addition of a binder based on liquid cured polymers results in a material that exhibits favorable thermal insulating and sound insulating properties. The sound absorption coefficient was

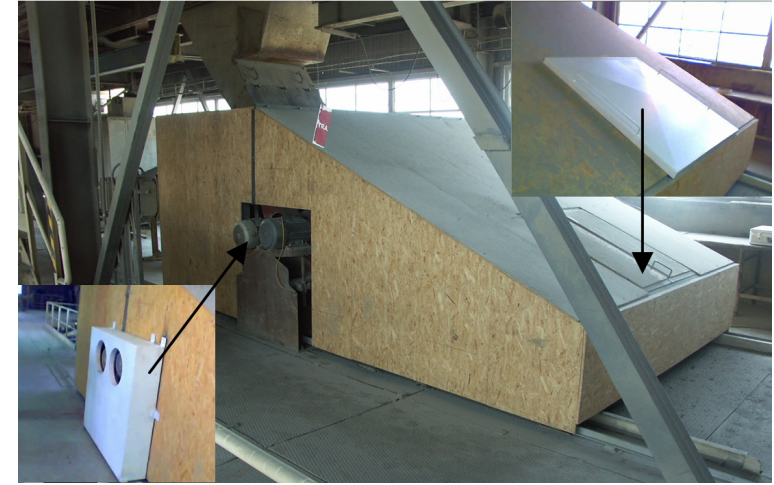

Fig. 10. Realized sound insulating enclosure

determined by its own measurements by the impedance tube and is graphically illustrated in Fig. 9. The methodology and procedure for measuring and determining the sound absorption of materials are described in more detail $[24 \div 26]$.

\section{RESULTS AND DISCUSSION}

Realized sound insulating enclosure with detailed views of the maintenance door design and the drive cover with the belt gears is shown in Fig. 10. The casing of the drive with belt gear has been designed with openings for natural cooling.

The results of measurements of the A - weighted equivalent sound pressure level of the vibrating sorter without sound insulating enclosure and with the installed sound insulating enclosure in both operating modes are shown in Table 1.

Fig. 11 shows a comparative graph of the values of $\mathrm{A}$ - weighted equivalent sound pressure level at the individual measurement points before and after the measures during the operation mode without sorting of stone fraction.

Measurement analysis in idle mode shows a reduction in the A - weighted equivalent sound pressure level between $8.5 \div 11 \mathrm{~dB}$ after the installation of sound insulating enclosure. In this case, the measurements were influenced by background noise, respectively noise from other technological units.

Fig. 12 is a comparative graph of the values of A - weighted equivalent sound pressure level at the individual measurement points before and after the measures taken during the sorting of stone fraction. Analysis of mode with stone sorting measurements indicates a reduction in the A - weighted equivalent sound pressure level in the range of $3 \div 5 \mathrm{~dB}$ after the installation of the sound insulating enclosure. When evaluating the effectiveness of sound insulating measures, it is 
Table 1. A - weighted equivalent sound pressure level $\mathrm{L}_{\text {Aeq.T }}$ before and after realization of the measures

\begin{tabular}{|c|c|c|c|c|}
\hline \multirow{2}{*}{$\begin{array}{c}\text { Measurement } \\
\text { points }\end{array}$} & \multicolumn{2}{|c|}{ Mode without stone fraction sorting } & \multicolumn{2}{c|}{ Mode with stone fraction sorting } \\
\cline { 2 - 5 } & Without enclosure & With enclosure & Without enclosure & With enclosure \\
\cline { 2 - 5 } & \multicolumn{3}{|c|}{ A- weighted equivalent sound pressure level $\mathrm{L}_{\text {Aeq. }}$ [dB] } \\
\hline P1 & 87.0 & 76.1 & 91.6 & 87.4 \\
\hline P2 & 87.2 & 78.4 & 91.6 & 88.1 \\
\hline P3 & 87.5 & 78.9 & 92.2 & 88.4 \\
\hline P4 & 87.5 & 76.1 & 92.1 & 88.6 \\
\hline P5 & 89.0 & 77.3 & 92.7 & 88.4 \\
\hline P6 & 85.9 & 77.4 & 90.5 & 87.8 \\
\hline
\end{tabular}

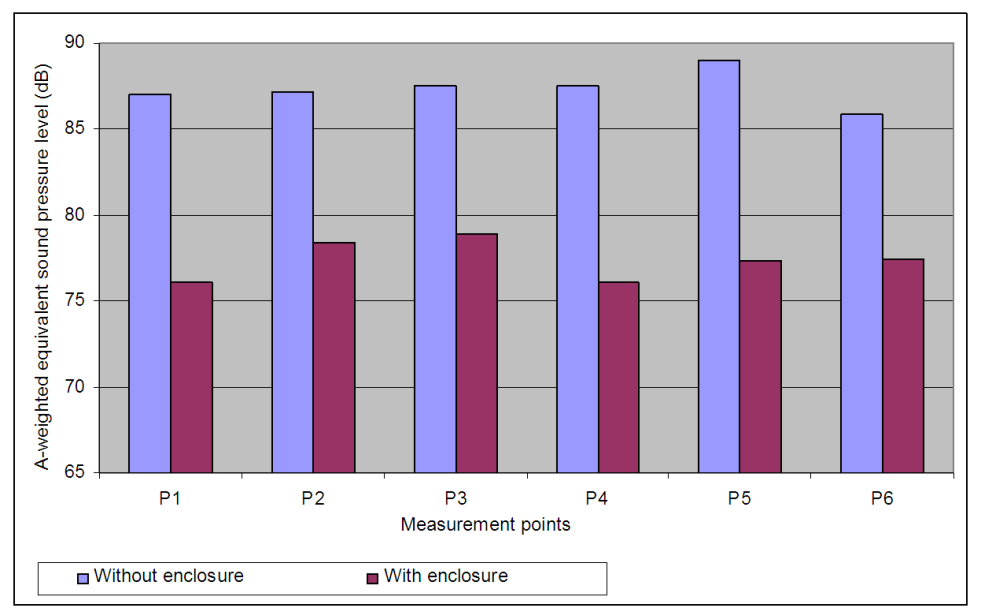

Fig. 11. Graphical comparison of the $\mathrm{L}_{\text {Aeq.T }}$ - mode without stone fraction sorting

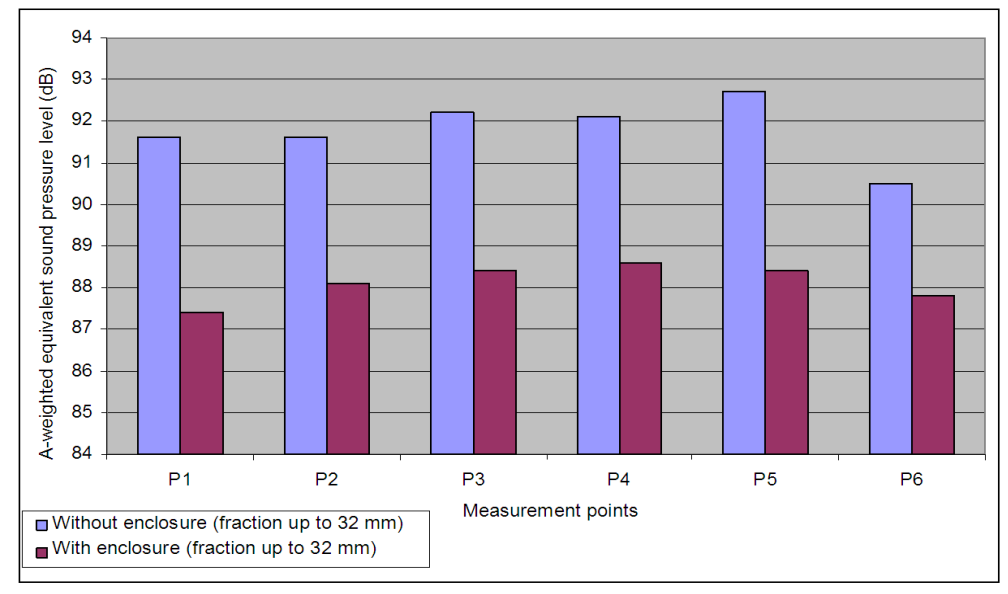

Fig. 12. Graphical comparison of the $\mathrm{L}_{\text {Aeq.T }}$ - mode with stone fraction sorting

necessary to take into account the noise of other technologies that had to be in operation due to the supply of the stone fraction to the vibration sorter.

Analysis of acoustic camera measurement results was performed using A - weighted frequency spectra. Comparison of the frequency spectra of the sound generated from the measurements in the
$\mathrm{K} 1$ and $\mathrm{K} 2$ measurement points in the operating mode during stone fraction sorting before (Fig. 13 and Fig. 15) and after (Fig. 14 and Fig. 16) the realization of the sound insulating measures.

From the comparison spectra in Fig. 13 and Fig. 14 they show that these sound insulation measures significantly reduced the noise level 


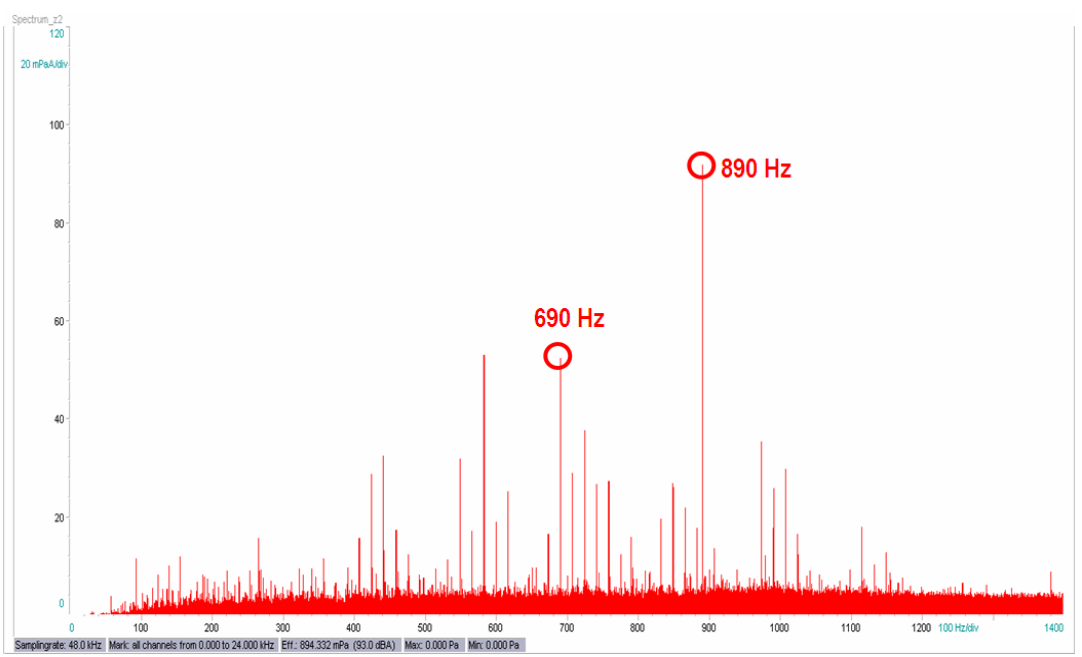

Fig. 13. Frequency spectrum in the measurement point K1 - without enclosure

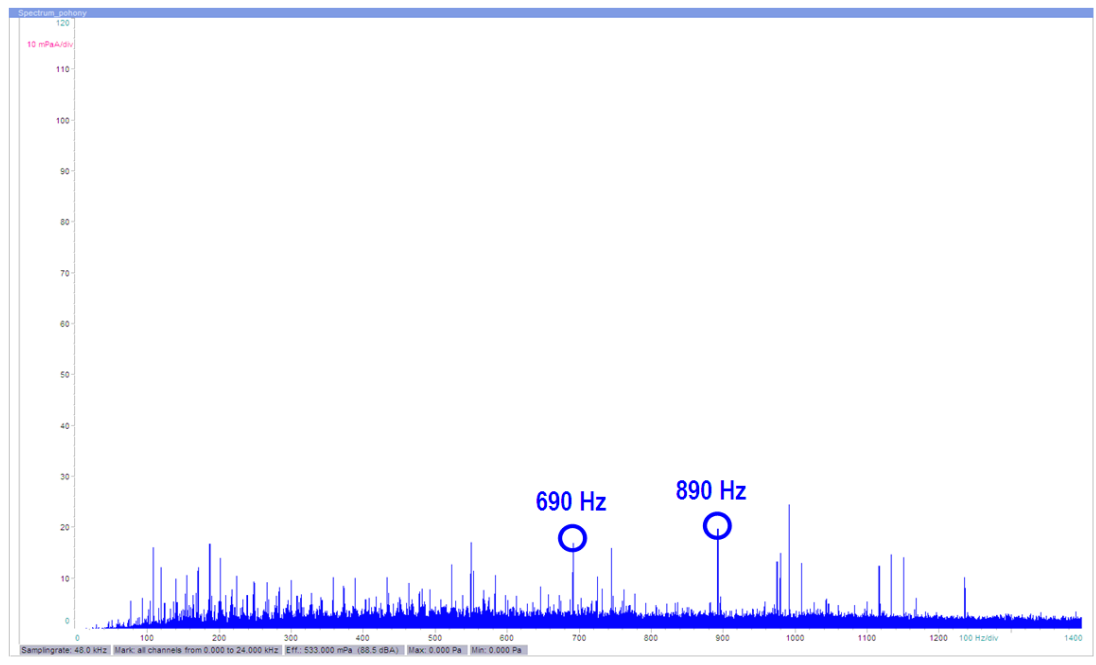

Fig. 14. Frequency spectrum in the measurement point K1 - with enclosure

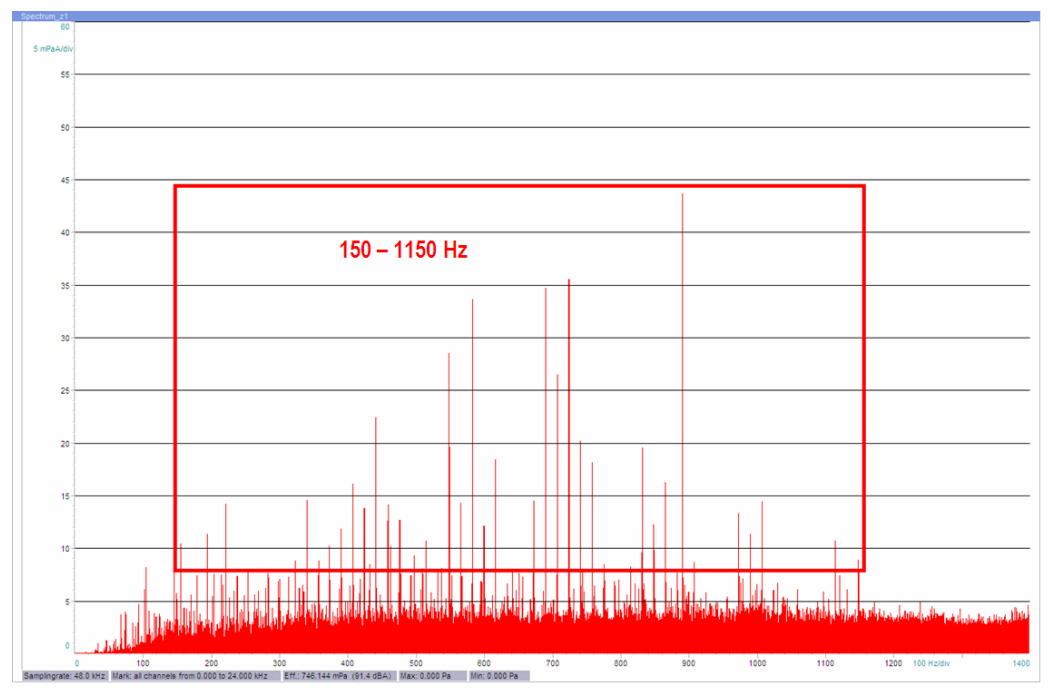

Fig. 15. Frequency spectrum in the measurement point $\mathrm{K} 2$ - without enclosure 


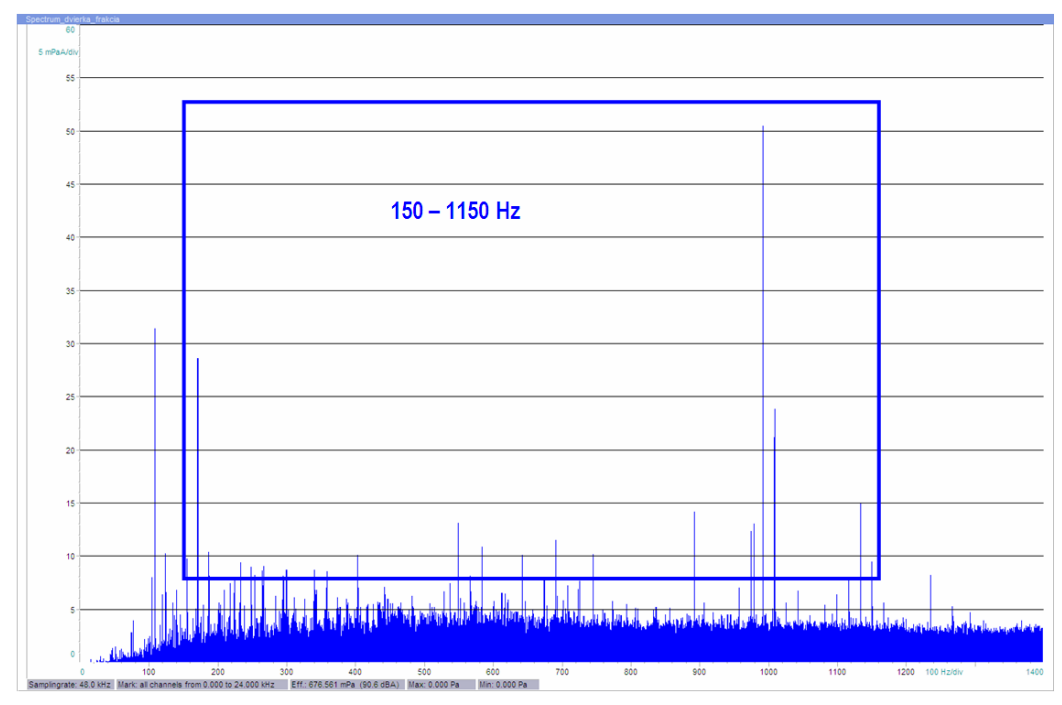

Fig. 16. Frequency spectrum in the measurement point K2 - without enclosure

at the frequencies emitted by the drive unit and belt gear components.

From the comparison in the frequency spectrum in Fig. 15 and Fig. 16, they show that, after covering the vibration sorter and the realization of additional sound insulating measures such as the isolation of the front maintenance doors, this reduced the noise levels of most frequencies. The increase of the sound pressure level occurred in the frequency range of $1000 \mathrm{~Hz}$ and at the frequency of $170 \mathrm{~Hz}$, which however may not be related to the sources of noise of the vibration sorter, since other technological sources of noise (conveyors and other sorting devices) which affect the acoustic situation in the surroundings of the vibrating sorter.

\section{CONCLUSIONS}

The presented work is focused on the solution of industrial noise sources in the working environment. Resolving noise from industrial sources is a demanding process that requires complex theoretical and practical knowledge in the field of acoustics, which must be based on science and research results. The most appropriate way to effectively reduce machine, mechanical and technological noise levels is to address this factor at the design and production stage. In practice, there are a large number of instances where noise issues are needed to be reduced by technical sound reducing measures on already operated equipment and machines. These noise reduction measures can be applied directly to noise sources, to the noise propagation transmission path, and to the persons receiving the noise. Noise reduction solutions by use of an acoustic visualization technique can serve as an aid to the faster and more efficient localization and analysis of partial noise sources. The concrete realization of the sound insulating enclosure of the vibrational sorter in the operation of a stone quarry was able to reduce the noise levels in its surroundings. A secondary effect of this measure is the reduction in the concentration of solid aerosols in the vicinity of the sorter.

\section{Acknowledgements}

This work was supported by the Slovak Research and Development Agency under the contract no. APVV 0432-12.

\section{REFERENCES}

1. Molnár V., Fedorko G., Stehlíková B., Tomašková M., Hulínová Z. Analysis of asymmetrical effect of tension forces in conveyor belt on the idler roll contact forces in the idler housing. Meas J Int Meas Confed. 52(1), 2014, 22-32.

2. Molnár V., Fedorko G., Stehlíková B., Michalik P., Kopas M. Mathematical models for indirect measurement of contact forces in hexagonal idler housing of pipe conveyor. Meas J Int Meas Confed. 47(1), 2014, 794-803.

3. Molnár V., Fedorko G., Stehlíková B., Michalik P., Weiszer M. A regression model for prediction of pipe conveyor belt contact forces on idler rolls. Meas J Int Meas Confed. 46(10), 2013, 3910-3917.

4. Debski H., Teter A., Kubiak T., Samborski S. Local buckling, post-buckling and collapse of thinwalled channel section composite columns sub- 
jected to quasi-static compression. Compos Struct. 136, 2016, 593-601.

5. Garbacz T., Jachowicz T., Gajdoš I., Kijewski G. Research on the influence of blowing agent on selected properties of extruded cellular products. Adv Sci Technol Res J. 2015, 9(28), 81-88.

6. Žiaran S. Znižovanie kmitania a hluku v priemysle. STU Bratislava, 2006.

7. Ver I.L., Beranek L.L. Noise and vibration control engineering: principles and applications. John Wiley and Sons Ltd. John Wiley \& Sons. Inc. Hoboken, New Jersey, 2006.

8. Döbler D., Heilmann G. Perspectives of the Acoustic Camera. In: Environmental Noise Control. The 2005 Congress and Exposition on Noise Control Engineering, 2015, 1-9.

9. Fischer S., Simmer K.U. Beamforming microphone arrays for speech acquisition in noisy environments. Speech Commun. 20(3-4), 1996, 215-227.

10. Johnson D.H., Dudgeon D.E. Array signal processing: concepts and techniques. 1992, 533 p.

11. Gauthier P.A., Camier C., Pasco Y., Berry A., Chambatte E., Lapointe R. et al. Beamforming regularization matrix and inverse problems applied to sound field measurement and extrapolation using microphone array. Journal of Sound and Vibration. 330, 2011, 5852-5877.

12. Malov E.A., Bronfin V.N., Dolgopyatov V.N., Pavlenko B.A., Kostyukov V.N., Bojchenko S.N. et al. Experience of large-scale introduction of COMPACS stationary systems for vibrodiagnostics. Khimiya i Tekhnologiya Topl i Masel. 1, 1997.

13. Urbanek J., Barszcz T., Zimroz R., Antoni J. Application of averaged instantaneous power spectrum for diagnostics of machinery operating under nonstationary operational conditions. Meas J Int Meas Confed. 45(7), 2012, 1782-1791.

14. Opocenska H., Hammer M. Use of technical diagnostics in predictive maintenance. In: 17th International Conference on Mechatronics - Mechatronika (ME). 2016, 1-6.

15. Huňady R., Hagara M., Schrotter M. The application of high-speed digital image correlation in vi- bration analysis of a rotating object. In: EAN 2012: Proceedings of the 50th Annual Conference on Experimental Stress Analysis. 2012.

16. Král' J. jr., Král' J. Verification of a three axis milling machine accuracy in the process of complex shaped part production. Appl Mech Mater. 474, 2014, 261-266.

17. Krajňák J., Homišin J., Grega R., Urbanský M. The analysis of the impact of vibrations on noisiness of the mechanical system. Diagnostyka. 17(3), 2016, 21-26.

18. Stejskal T., Kováč J., Valenčík Š. Mechanism of randomness in vibration signals of machinery. In: Applied Mechanics and Materials: ROBTEP 2012. 2012, 257-262.

19. Ingard U. Noise Reduction Analysis. Jones and Bartlett Publishers, Ontario, 2008.

20. Dolnik B. Contribution to analysis of daily diagram of supply voltage in low voltage network: Working days versus non-working days. In: Proceedings of the 2015 16th International Scientific Conference on Electric Power Engineering. EPE 2015, VŠBTU, 2015, 373-376.

21. Liptai R.G., Harris D.O. Materials Research and Standards. MTRSA. 11(3), 1971, 8.

22. Zajac J., Szabó D. Akustické požiadavky na deliace konštrukcie: priečky. STU Bratislava, 2009.

23. Zajac J et all. Znižovanie hluku a vibrácií v strojárskych prevádzkach. Alfa Bratislava, 1990.

24. Liptai P., Moravec M., Badida M. Research of possibilities of using the recycled materials based on rubber and textiles combined with vermiculite material in the area of noise reduction. Adv Mater Res. 1001, 2014.

25. Kuczmarski M.A., Johnston J.C. Acoustic Absorption in Porous Materials. Nasa/Tm-2011-216995 2011, 1-20.

26. Dalmont J.P. Acoustic impedance measurement. Part I: A Review. J Sound Vib. 243(3), 2001, 427-439.

27. STN EN ISO 11690-2: 1999. Akustika. Odporúčané postupy na navrhovanie nízkohlučných pracovísk vybavených strojovými zariadeniami. Čast' 2: Opatrenia na znižovanie hluku. 1999. 